\title{
14 University
}

Adams, R. B., Akyol, A. C. and Verwijmeren, P. (2018) Director skill sets. Journal of Financial Economics, 130(3), pp. 641-662. (doi:

$\underline{10.1016 / j . j f i n e c o .2018 .04 .010)}$

The material cannot be used for any other purpose without further permission of the publisher and is for private use only.

There may be differences between this version and the published version. You are advised to consult the publisher's version if you wish to cite from it.

http://eprints.gla.ac.uk/143926/

Deposited on 13 July 2017

Enlighten - Research publications by members of the University of Glasgow http://eprints.gla.ac.uk 